\title{
Forest Role and Influence on Agricultural Production and Food Security
}

\author{
Patarkalashvili T* \\ Technical University Of Georgia, Center studying Productive Forces and Natural Resources of Georgia, Georgia
}

Submission: January 17, 2019; Published: February 21, 2019

*Corresponding author: Patarkalashvili T, Technical University of Georgia, Center Studying Productive Forces and Natural Resources of Georgia, 69, M. Kostava str. Tbilisi, 0175, Georgia

Keywords: Forests role; Wood products; Biodiversity; Forest degradation; Carbon dioxide; Climate change

\section{Food will Last so Long as Forests do".....so Runs an Ancient Kashmiri Adage}

Forests and the benefits they provide in form of food, income and watershed protection have an important and often critical role in enabling people in the world to secure a stable and adequate food production and supply. Forests are very important in food secure as they are one of the most accessible productive resource available. Good nutrition is most essential for people, as well as, for economic development of the world. The right for food is a basic human right and so one of the main goals of mankind development [1-2].

In addition to wood products, non-wood forest resources and biomass, other benefits of forests to on-site users also can be included protection of soils from erosion and water flow regulation, as well as shade and windbreak protection, amelioration. Forest degradation involves the loss of ground cover, expose of soil to rainfalls that can result in increased erosion. The loss of nutrient-rich topsoil can result in significant decrease in agricultural productivity. Loss of ground cover in local watersheds can become a reason for increased erosion, leading to sedimentation of waterways which may have negative impact on downstream irrigation, fishery and dam operations [3-4].

In Highland countries forests have extremely critical importance for minimizing ecological and environmental diverse effects like erosion, landslides, mud-torrents, rock-falls. They defend highland population from strong, cold winds and avalanches. In mountain spar resorts they regulate the penetration of rain-flow slowly and maintain mineral water output. In arid environments, forests are crucial to food security in dry seasons. Forests assure such environmental functions as biodiversity, water and soil conservation, water supply and climate regulation; they provide habitats to about two thirds of all species on earth;
Two very important services also provided by forest ecosystems which benefit the global community are carbon sequestration and storage and conservation of biodiversity through provision of habitat for diverse plant and animal species. Forests are considered the most species-diverse terrestrial habitat on the planet. For example, the tropical moist forests are home to 50-90 percent of the Earth's terrestrial species [5].

Human society and the global economy are closely linked to forests. More than one billion people depend on forests for their livelihoods and forests ecosystems play the critical role in stabilizing the global climate, providing food, water, wood products, medicinal plants and herbs. Deforestation and forest degradation that takes place in the world accounts up to 20 percent of the global greenhouse gas emissions that contribute to global warming. Despite decreased deforestation rates for last years, in some regions of the world forest ecosystems are still under great threat. According to WRI (World Resources Institute), 30\% of global forests cover has already been cleaned, while another $20 \%$ has been degraded. Most of the rest has been fragmented, leaving only 15\% intact [6]. The World Economic Forum's Global Shaper's survey in 2017 named N1 problem of our planet - Climate Change and Destruction of Nature (48.8\%) [7].

Experts from all over the world taking part in the 48th Session of the IPCC (Intergovernmental Panel on Climate Change) in Incheon, South Korea, warned that Earth has only until 2030 to stem catastrophic climate change. It focuses on the impacts of global warming reaching 1.5 degrees Celsius above pre-industrial levels. They have also underlined, that the planet is already on the two-thirds of the way to there, with global temperature having warmed about 1-degree $\mathrm{C}$. The experts also underlined that global net emissions of carbon dioxide should fall by 45\% from 2010 
levels by 2030 and reach, net zero" around 2050 in order to keep the warming on 1.5 degrees Celsius [8].

We think that gaining this aim will be difficult without sufficient decreasing levels of deforestation and forest degradation in the world, so we propose that the FAO, World Forest Watch, UNEP, IUCN, IPCC, WWF and other NGO environment protective organizations should work out quotas on annual principal loggings, especially to most forest rich countries which overexploit their forests, with strong monitoring and appropriate sanctions, leaving intact only sanitary and nursery loggings in young forests. Forests growing in these countries don't belong to them only, they belong to the whole mankind and other living organisms who have right to live and breathe clean air. Those countries occupied by increased overexploitation of forests must restrain their appitates.

To stop long-term excessive loggings resulted in forest degradation and reduce greenhouse gas emissions from deforestation and forest degradation some countries (China, Indonesia) has already launched moratoriums on loggings in their countries. For example: China launched moratorium on 40years [9] and Indonesia launched the nationwide moratorium on new license areas(concessions) for oil palm plantations, timber plantations and logging activity in primary forests and pert lands since May 2011. They believe that the moratorium will offer a valuable opportunity for their forests to recover from excessive loggings, as well as a chance to develop sustainable management regimes and accumulate relevant technology. It is a wonderful example for other countries to follow in attempt to save our planet.

\section{References}

1. Hoskins M (1985) The promise in trees. Food and Nutrition 11(2): 4446.

2. Lipper L (2000) Forest degradation and food security. Unasylva 51(202).

3. Vladishevsky D, Laletin A, Vladishevsky A (2000) Role of wildlife and other non-wood forest products in food security in central Siberia. Unasylva 202(51).

4. FAO (1989) Forestry and Food Security. Forestry paper 90, Rome, Italy.

5. Sene EH (1985) Trees, food production and the struggle against desertification. Unasylva 37(150): 19-26.

6. Global Forest Watch. Small Grants Fund.

7. (2017) World Economic Forum Global Shapers Survey.

8. Limin Dai, Shanlin Li, Wang-ming Zhou, Lin Qi (2018) Opportunities and challenges for the protection and ecological functions promotion of natural forests in China. Forest Ecology and Management 410: 187192.

9. Jonah Busch, Ferretti-Gallon K, Engelmann J, Wright M, Austin KG, et al (2015) Reductions in emissions from deforestation from Indonesia's moratorium on new oil palm, timber, and logging concessions. Proc Natl Acad Sci U S A 112(5): 1328-1333.

\section{Your next submission with Juniper Publishers will reach you the below assets}

- Quality Editorial service

- Swift Peer Review

- Reprints availability

- E-prints Service

- Manuscript Podcast for convenient understanding

- Global attainment for your research

- Manuscript accessibility in different formats

( Pdf, E-pub, Full Text, Audio)

- Unceasing customer service

Track the below URL for one-step submission https://juniperpublishers.com/online-submission.php 